\title{
Pemetaan Base Transceiver Station Berbasis WebGIS: Studi Kasus Kecamatan Jatinegara
}

\author{
ZAENI ARIF ${ }^{1}$, FERI NUGROHO ${ }^{2}$, RISMA EKAWATI ${ }^{3}$ \\ 1,2,3Universitas Global Jakarta, Indonesia \\ Email : ferinugroho@jgu.ac.id
}

Received 24 September 2021 | Revised 22 Oktober 201x | Accepted 25 Oktober 2021

\begin{abstract}
ABSTRAK
WebGIS merupakan salah satu pemetaan digital yang berbasis website yang saat ini tengah berkembang pesat. Pemanfaatan webgis dapat digunakan sebagai pemetaan sebuah lokasi bangunan yang nantinya memberikan informasi kepada masyarakat. Salah satunya yaitu sebagai pemetaan lokasi BTS di kecamatan Jatinegara. Pemetaan BTS tersebut, diharapkan dapat memberikan informasi secara public yang dapat di akses oleh masyarakat khususnya di kecamatan Jatinegara. Dalam webgis tersebut juga menampilkan keterangan berupa alamat BTS secara lengkap. Dalam pengembangan sistem webgis ini, peneliti menggunakan metode waterfall dan untuk perancangan sistem menggunakan Unifed Modeling Language (UML). Serta dalam pengujiannya menggunakan blackbox testing untuk mengetahui apakah sistem yang dikembangkan sudah sesuai kegunaan dan fungsinya. Dari hasil pengujian tersebut webgis yang kembangkan telah berjalan sesuai kebutuhan dan tidak terdapat kesalahan syntak.
\end{abstract}

Kata kunci: WebGIS, Sistem Informasi Geografis, Pemetaan

\begin{abstract}
WebGIS is a website-based digital mapping which is currently growing rapidly. Utilization of webgis can be used as a mapping of a building location which will later provide information to the public. One of them is as a mapping of BTS locations in Jatinegara sub-district. The BTS mapping is expected to provide public information that can be accessed by the public, especially in the Jatinegara sub-district. The webgis also displays information in the form of a complete BTS address. In developing this webgis system, researchers used the waterfall method and for system design using the Unified Modeling Language (UML). As well as in the test using blackbox testing to find out whether the system developed is in accordance with its uses and functions. From the test results, the webgis that was developed has been running as needed and there are no syntax errors.
\end{abstract}

Keywords: WebGIS, Geographic Information System, Mapping 


\section{PENDAHULUAN}

Pesatnya perkembangan ilmu pengetahuan selalu didampingi dengan kemajuan teknologi. Perkembangan teknologi tersebut telah banyak membawa perubahan dalam berpikir, bersosialisasi, dan tingkah laku (Setiawan, 2017). Teknologi informasi seperti website saat ini telah banyak dimanfaatkan untuk berbagai kegiatan yang bermanfaat seperti berkomunikasi, pekerjaan, informasi bencana, dan lain sebagainya (Rahmasari, et al., 2021).

Jumlah pelanggan jasa telekomunikasi semakin bertambah seiringan dengan kemajuan teknologi yang saat ini berkembang semakin cepat. Penyedia jasa telekomunikasi selular juga semakin bertambah, maka mengharuskan mendirikan menara telekomunikasi Base Transceiver Station (BTS). Menara BTS sangat penting untuk menjangkau layanan telekomunikasi selular di sebuah daerah sehingga pelanggan jasa telekomunikasi mendapatkan sinyal selular (Muttaqin, 2017). Dari sebuah BTS dihasilkan radiasi yang ditimbulkan, bagi masyarakat sekitar yang bertempat tinggal dekat dengan BTS tersebut tidak mengetahui seberapa besar radiasi dari BTS tersebut (Hananto, 2014). Di Indonesia sendiri masih banyak masyarakat yang belum peduli serta memilih tinggal di sekitar BTS. Selain itu, kurangnya pengetahuan tentang dampak buruk radiasi gelombang elektromagnetik bagi Kesehatan (Ramadhani, et al., 2019).

Salah satu pemanfaatan teknologi untuk pemetaan lokasi suatu tempat yang saat ini berkembang yaitu sistem informasi geografis (Nugroho \& Al-Sanjary, 2018). Sistem informasi geografis ini juga membantu untuk menghasilkan suatu informasi lokasi yang berasal dari pengolahan data spasial (Ferdiansyah, 2017). Dengan pemanfaatan teknologi ini kita dapat mengetahui informasi tentang letak suatu objek yang ada di atas permukaan bumi serta dampak ke sekeliling objek itu sendiri (Julianti, et al., 2018).

Sistem informasi geografis berbasis web atau webGIS memang sudah banyak digunakan di berbagai bidang dan juga sudah banyak dijadikan penelitian oleh mahasiswa tingkat akhir karena webGIS tersebut menggabungkan antara web design dan web pemetaan (Muliyadi, et al., 2015). Semakin pesatnya perkembangan teknologi informasi, maka dibutuhkan berbagai inovasi untuk mengembangkan teknologi informasi yang bermanfaat untuk semua orang. Salah satunya informasi tentang jangkauan radius radiasi dari sebuah BTS yang dapat di akses dan dilihat oleh masyarakat. Penelitian yang penulis lakukan ini memberikan kemudahan untuk mendapatkan informasi letak BTS di sebuah daerah dan luas radiasi yang dihasilkan oleh BTS tersebut (Kurniawan \& Ahyuni, 2019).

Open Street Map merupakan salah satu data peta yang paling banyak digunakan untuk webgis, sebab dengan menggunakan data tersebut informasi yang dihasilkan dapat mencangkup informasi secara global (Annugerah, et al., 2016). Selain itu, penggunaan file GeoJSON yang berisikan longtitude dan latitude tentang lokasi BTS serta penggunaan Google Maps API diharapkan dapat memberikan informasi tentang letak dan jangkauan radiasi BTS (Hairah \& Budiman, 2017).

Setelah titik koordinat lokasi BTS didapatkan, maka langkah selanjutnya yaitu penerapan ke dalam sebuah webgis. Dengan penerapan ke dalam webgis masyarakat dapat mengakses informasi letak dan jangkauan radiasi BTS secara mudah dengan menggunakan web browser (Mertha, et al., 2019). 


\section{METODE}

\subsection{Metode Penelitian}

Pada penelitian ini menggunakan metode observasi objek secara langsung dan pengamatan pada lokasi Base Transceiver Station dengan menentukan titik latitude dan longitude. Untuk pengembangan sistem menggunakan metode waterfall. Menurut Pressman (2015), metode waterfall merupakan model pengembangan sistem informasi yang sistematik dan sekuensial. Pengembangan perangkat lunak dalam pengembangannya melalui tahapan-tahapan, requirement (analisis kebutuhan), design system (desain sistem), coding (pengkodean) \& testing (pengujian), penerapan program, dan pemeliharaan (Sasmito, 2017).

Dalam membuat rancangan pengembangan sistem digunakan Unified Modeling Language (UML). Penggunaan UML dalam pengembangan sistem telah di jelaskan oleh Rosa dan Shalahuddin, yang berpendapat bahwa Unified Modeling Language (UML) adalah "Salah standar bahasa yang banyak digunakan di dunia industri untuk mendefinisikan requirement, membuat analisa \& desain, serta menggambarkan arsitektur dalam pemrograman berorientasi objek" (Pratama \& Junianto, 2016). UML (Unified Modeling Language) juga dapat diartikan sebagai bahasa yang sering digunakan untuk membangun sebuah sistem perangkat lunak dengan melakukan penganalisaan desain dan spesifikasi dalam pemrograman berorientasi objek (Sari, 2020).

\subsection{Objek Dan Lokasi Penelitian}

Objek penelitian yang akan diambil yaitu sebuah Base Transceiver Station untuk mendapatkan letak longitude, latitude, dan radiasi dari BTS tersebut. Lokasi penelitian yaitu Kecamatan Jatinegara yang berlokasi di Kota Jakarta Timur. Waktu penelitian dilakukan pada bulan November sampai Desember 2020.

\subsection{Rancangan Penelitian}

Rancangan diagram alur dalam penelitian ini dapat dilihati pada Gambar 1.

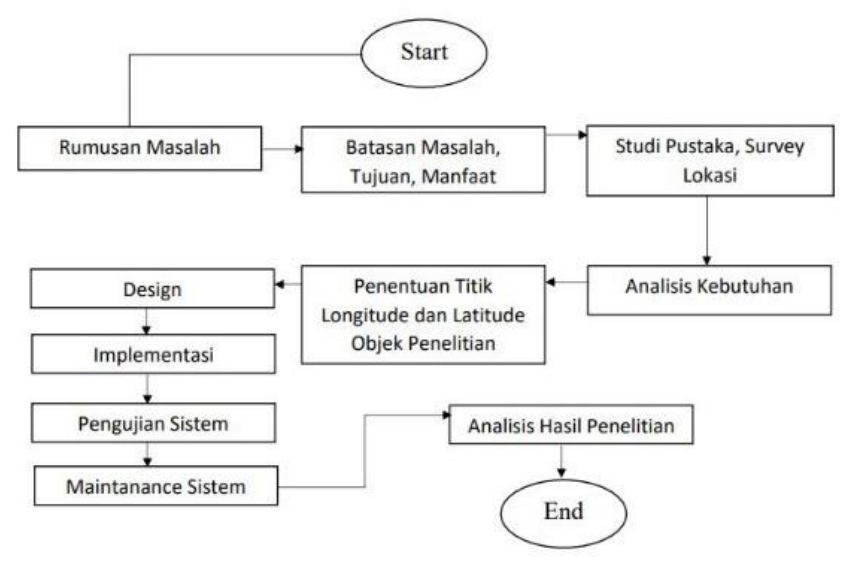

Gambar 1. Diagram Alur Penelitian

\subsection{Tahap Pembuatan Sistem}

Tahap pembuatan WebGIS untuk Pemetaan Base Transceiver Station Kecamatan Jatinegara, digunakan model waterfall. Model ini membangun sebuah sistem secara sistematis atau berurutan. 


\subsubsection{Analisis Kebutuhan}

Analisis kebutuhan merupakan tahap pertama dari model waterfall dalam membangun suatu sistem untuk menentukan kebutuhan sistem, yang meliputi deskripsi sistem, analisis kebutuhan fungsional, dan analisis kebutuhan nonfungsional (kebutuhan selain fungsi).

\section{Deskripsi Sistem}

SIG untuk Pemetaan Base Transceiver Station di Kecamatan Jatinegara merupakan sistem informasi geografis berbasis web yang menampilkan informasi tentang penyebaran BTS di Kabupaten Jatinegara. Sistem ini dapat memberikan informasi yang akurat kepada masyarakat tentang lokasi BTS serta radiasi dari BTS melalui website.

2. Kebutuhan Fungsional

Ada dua jenis pengguna dalam Webgis pemetaan BTS di Kecamatan Jatinegara yaitu pengguna dan admin, masing-masing dengan hak akses yang berbeda. Setiap pengguna memiliki hak akses berikut.

\section{a. Administrator}

Administrator memiliki hak akses untuk mengelola data lokasi BTS di Kecamatan Jatinegara, seperti mengedit file geojson untuk menentukan lokasi dan area.

b. User

Hak akses User antara lain mengetahui sebaran lokasi BTS di Kecamatan Jatinegara dan radiasi yang dipancarkan oleh BTS tersebut. Informasi tersebut ditampilkan dalam bentuk peta, alamat, dan HeatMap.

Fungsi-fungsi operasi peta yang dimiliki sistem sebagai berikut:

1. Menampilkan peta wilayah Kelurahan pada Kecamatan Jatinegara

2. Menampilkan letak lokasi BTS

3. Menampilkan HeatMap radiasi dari BTS tersebut.

\subsubsection{Penentuan Titik}

Untuk menentukan sebuah batas kelurahan dengan data polygon menggunakan Google Earth dan menentukan sebuah titik ploting yang akan dijadikan ke dalam file geoJSON.

Untuk menentukan sebuah titik longitude dan latitude dari sebuah BTS menggunakan Google Maps yang akan didatangi langsung ke objek penelitian. Dengan mendatangi langsung maka titik data yang akan diolah lebih akurat.

\subsubsection{Design}

Dalam menggambarkan alur sistem digunakan UML (Unified Modeling Language) yang nantinya dijadikan acuan dalam membuat tampilan antarmuka pengguna, layout pada website.

\subsubsection{Implementasi}

Dalam praktiknya, penulis menggunakan bahasa pemrograman PHP murni dengan menggunakan tambahan Leaflet sebagai library penampilan peta pada website.

\subsubsection{Pengujian Sistem}

Untuk menguji kelayakan dan mendapat masukan untuk pengembangan sistem, penulis melakukan pengujian sistem dengan cara blackbox testing.

\subsubsection{Maintenance}

Maintenance atau pemeliharaan sistem dilakukan penulis secara berkala dimulai saat penulis mengimplementasikan design yang dibuat dalam coding. 


\subsection{Metode Pengumpulan Data}

Peneliti melakukan tiga tahapan penelitian dalam perancangan sistem informasi geografis berbasis web untuk pemetaan BTS di Kecamatan Jatinegara yaitu tahap studi pustaka, tahap wawancara, dan tahap survei lokasi.

\subsubsection{Studi Pustaka}

Berbagai data dan informasi terkait penelitian dikumpulkan dengan cara melakukan studi pustaka melalui buku, jurnal, internet, dan situs internet.

\subsubsection{Survei Lokasi}

Survei lokasi dilakukan dengan cara mencari dan mendatangi BTS yang ada pada Kecamatan Jatinegara sehingga mendapatkan titik longitude dan latitude yang akan diinput pada sistem.

\subsection{Rancangan Alur Pengerjaan Penelitian}

Use Case Diagram sistem informasi berbasis webGIS di wilayah Jatinegara dapat dilihat pada Gambar 2.

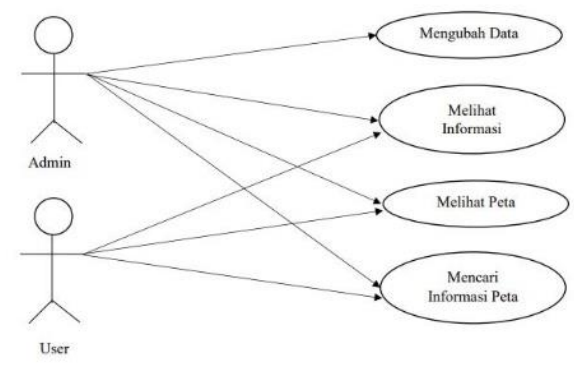

Gambar 2. Use Case Diagram

Flowchart yang dibuat pada webGIS pemetaan BTS ini bisa dilihat pada Gambar 3.

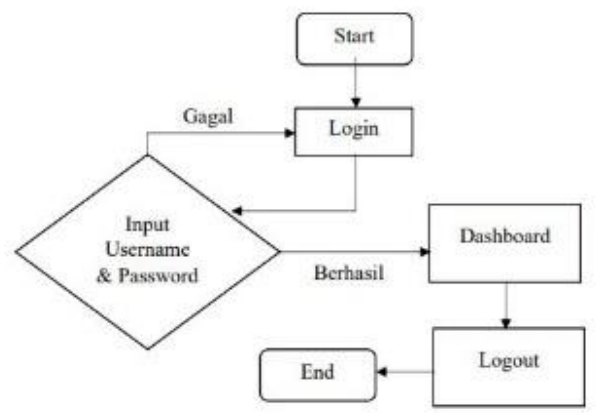

\section{Gambar 3. Flow Chart WebGIS BTS}

Activity Diagram menggambarkan proses yang terjadi pada use case aktivitas pada sistem yang sedang dirancang, dari awal sampai akhir. Berikut adalah gambar activity diagram user dan admin dalam melakukan login ke dalam sistem. 


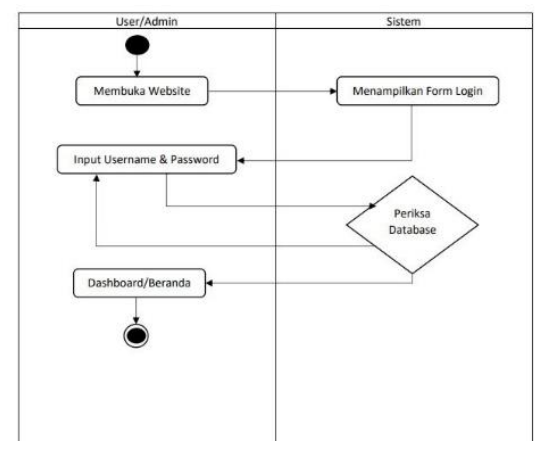

Gambar 4. Activity Diagram

Diagram kelas adalah diagram struktural yang mewakili kumpulan kelas, antarmuka, kolaborasi, dan hubungan (Nikiforova et al., 2012). Gambar 5 merupakan rancangan dari class diagram dalam pembuatan sistem pada penelitian ini.

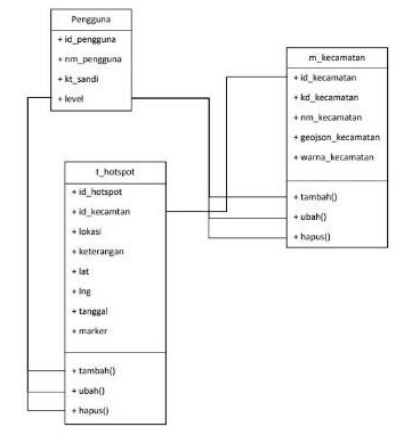

Gambar 5. Class Diagram

\section{HASIL DAN PEMBAHASAN}

Implementasi sistem ini akan menampilkan user interface dari website yang sudah dibuat oleh penulis. Halaman Administrator ini merupakan halaman yang dapat diakses untuk memperbarui data-data yang tersedia di dalam website tersebut. Halaman administrator ini terdiri dari; halaman login, halaman beranda, halaman data wilayah, data BTS, peta, bantuan.

\subsection{Implementasi Data Wilayah}

Implementasi data wilayah Kecamatan Jatinegara penulis mendapatkan dari internet. Data kelurahan dengan batasannya penulis membuat sendiri dengan membuat data polygon terlebih dahulu. Data polygon yang penulis buat dengan bantuan website https://geojson.io/ untuk membuat titik-titik sudut dari setiap batas kelurahan.

\subsection{Implementasi Basis Data}

Implementasi database MySQL digunakan untuk mendukung sistem yang dibangun. Berikut adalah implementasi daftar tabel dari database webgisphp: 
Pemetaan Base Transceiver Station Berbasis WebGIS: Studi Kasus Kecamatan Jatinegara

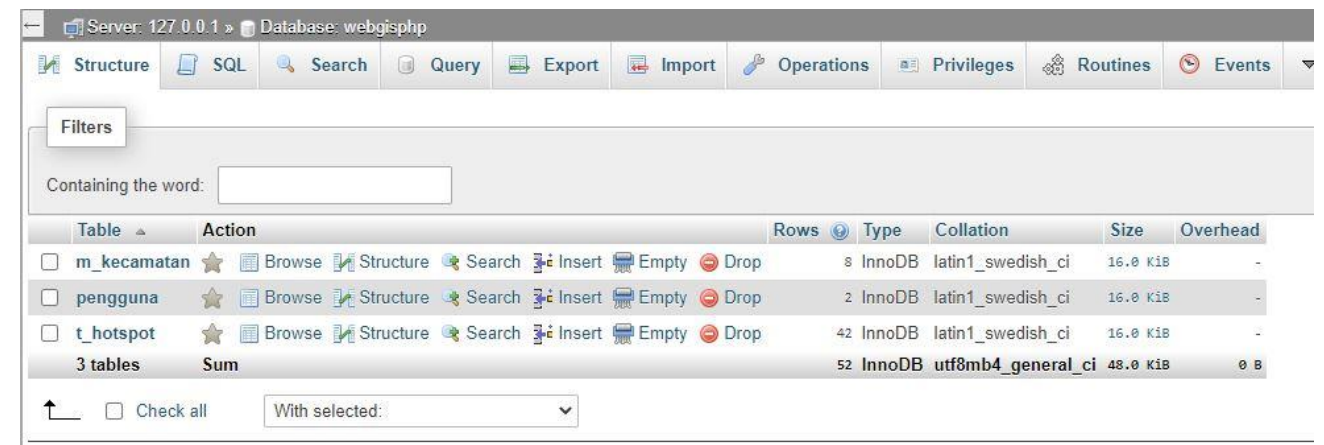

Gambar 6. Tabel Database

Berikut adalah isi dari tabel m_kelurahan:

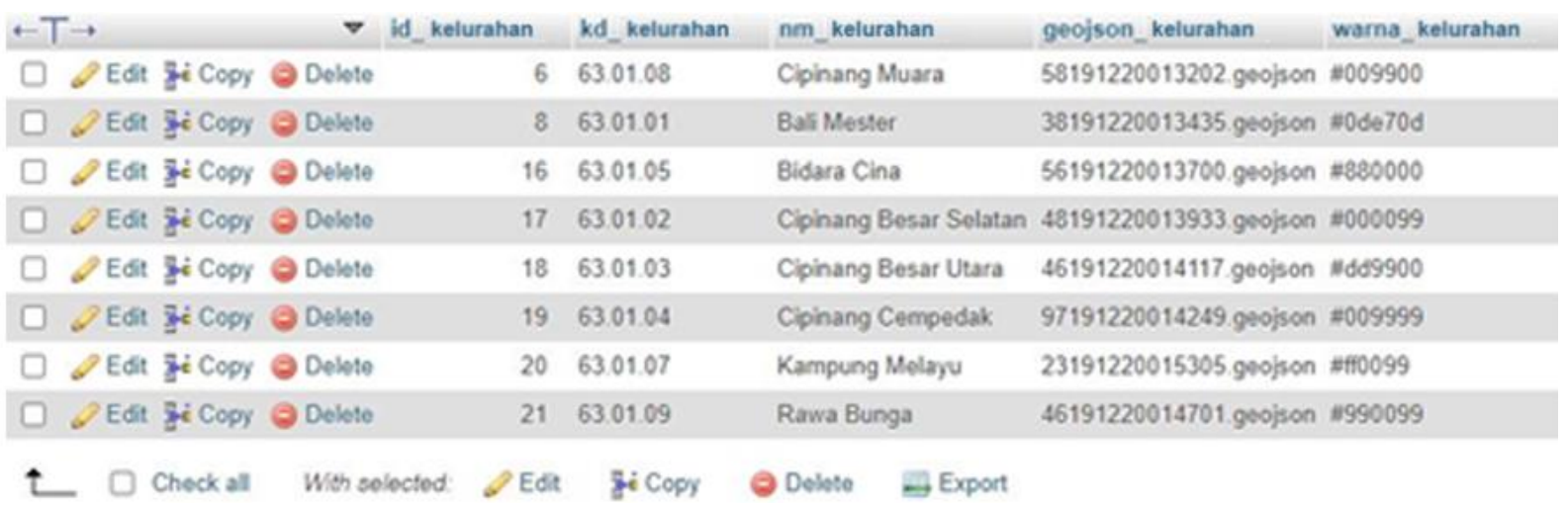

\section{Gambar 7. Tabel Database Kelurahan Pada Kecamatan Jatinegara}

Halaman Administrator ini merupakan halaman yang dapat diakses untuk memperbarui datadata yang tersedia di dalam website tersebut. Halaman administrator ini terdiri dari, halaman login, halaman beranda, halaman data wilayah, data BTS, peta, bantuan.

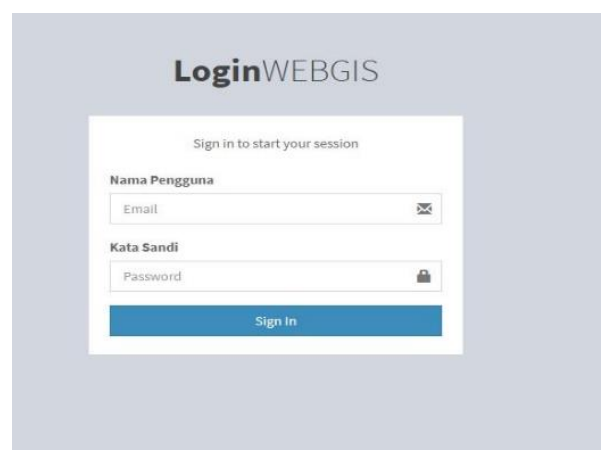

\section{Gambar 8. Halaman Login}

Untuk mengubah data kelurahan dapat dilihat pada gambar berikut ini. 


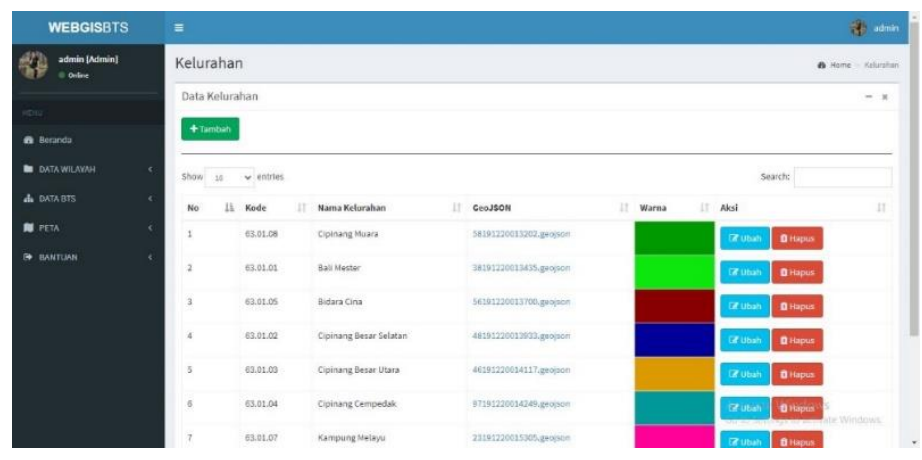

Gambar 9. Ubah Data Kelurahan

Untuk mengubah data BTS dapat dilihat pada gambar berikut.

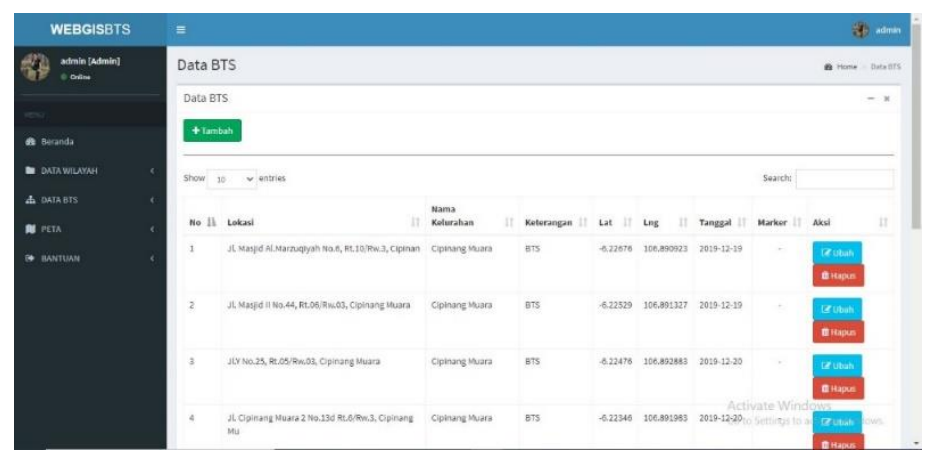

Gambar 10. Ubah Data BTS

Halaman user ini merupakan halaman yang dapat diakses hanya untuk melihat data-data yang tersedia di dalam website tersebut. Halaman user ini terdiri dari; halaman login, halaman beranda, peta, dan bantuan.

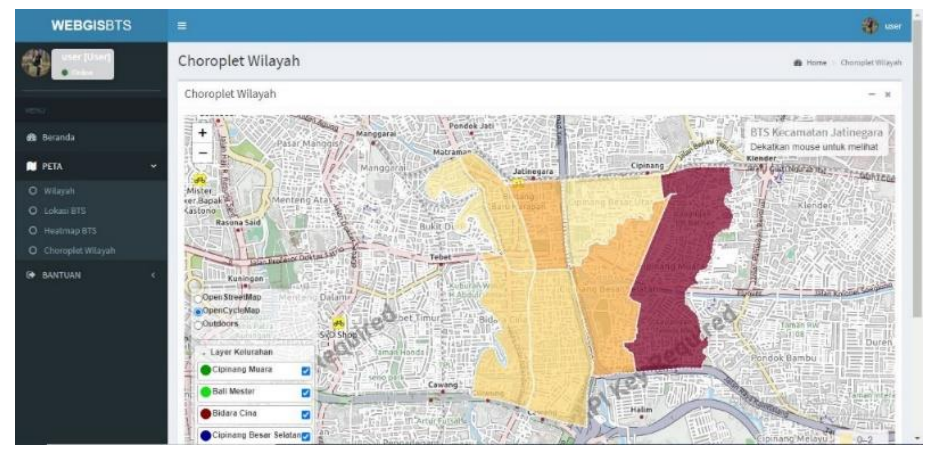

Gambar 11. Tampilan User

\subsection{Pengujian BlackBox}

Pengujian Blackbox ini akan memberikan hasil dari fitur-fitur yang tersedia pada website yang telah penulis buat. Berikut adalah tabel hasil dari BlackBox testing: 
Tabel 1. Hasil Uji BlackBox

\begin{tabular}{|c|c|c|c|c|c|}
\hline No & Nama Penguji & Masukan & $\begin{array}{c}\text { Hasil yang } \\
\text { diharapkan }\end{array}$ & Keluaran & $\begin{array}{c}\text { Hasil } \\
\text { pengujian }\end{array}$ \\
\hline 1 & $\begin{array}{l}\text { Pengujian login } \\
\text { untuk admin dan } \\
\text { user }\end{array}$ & $\begin{array}{l}\text { Masukkan email dan } \\
\text { password }\end{array}$ & $\begin{array}{l}\text { Muncul tampilan } \\
\text { beranda }\end{array}$ & $\begin{array}{l}\text { Sesuai yang } \\
\text { diharapkan }\end{array}$ & Berhasil \\
\hline 2 & $\begin{array}{l}\text { Pengujian pilihan } \\
\text { peta pada } \\
\text { beranda }\end{array}$ & $\begin{array}{l}\text { Klik peta yang akan } \\
\text { dipilih }\end{array}$ & $\begin{array}{l}\text { Muncul tampilan peta } \\
\text { sesuai pilihan }\end{array}$ & $\begin{array}{l}\text { Sesuai yang } \\
\text { diharapkan }\end{array}$ & Berhasil \\
\hline 3 & $\begin{array}{l}\text { Pengujian tombol } \\
\text { zoom pada peta }\end{array}$ & $\begin{array}{l}\text { Klik tanda +/- pada } \\
\text { peta }\end{array}$ & $\begin{array}{l}\text { Memberikan zoom } \\
\text { in/out pada peta }\end{array}$ & $\begin{array}{l}\text { Sesuai yang } \\
\text { diharapkan }\end{array}$ & Berhasil \\
\hline 4 & $\begin{array}{l}\text { Pengujian menu } \\
\text { layer kelurahan }\end{array}$ & $\begin{array}{l}\text { Klik tanda ceklis } \\
\text { pada salah satu } \\
\text { kelurahan }\end{array}$ & $\begin{array}{l}\text { Tampil/tidak tampil } \\
\text { polygon kelurahan }\end{array}$ & $\begin{array}{l}\text { Sesuai yang } \\
\text { diharapkan }\end{array}$ & Berhasil \\
\hline 5 & $\begin{array}{l}\text { Pengujian hide } \\
\text { dan close peta }\end{array}$ & $\begin{array}{l}\text { Klik tanda -/x pada } \\
\text { bagian kanan peta }\end{array}$ & $\begin{array}{l}\text { Menyembunyikan dan } \\
\text { menghilangkan peta }\end{array}$ & $\begin{array}{l}\text { Sesuai yang } \\
\text { diharapkan }\end{array}$ & Berhasil \\
\hline 6 & $\begin{array}{l}\text { Pengujian data } \\
\text { wilayah }\end{array}$ & $\begin{array}{l}\text { Klik tambah wilayah, } \\
\text { ubah, dan hapus }\end{array}$ & $\begin{array}{l}\text { Dapat menambah, } \\
\text { mengubah, dan } \\
\text { menghapus wilayah }\end{array}$ & $\begin{array}{l}\text { Sesuai yang } \\
\text { diharapkan }\end{array}$ & Berhasil \\
\hline 7 & $\begin{array}{l}\text { Pengujian data } \\
\text { BTS }\end{array}$ & $\begin{array}{l}\text { Klik tambah BTS, } \\
\text { ubah, dan hapus }\end{array}$ & $\begin{array}{l}\text { Dapat menambah, } \\
\text { mengubah, dan } \\
\text { menghapus BTS }\end{array}$ & $\begin{array}{l}\text { Sesuai yang } \\
\text { diharapkan }\end{array}$ & Berhasil \\
\hline 8 & $\begin{array}{l}\text { Pengujian chroplet } \\
\text { peta }\end{array}$ & $\begin{array}{l}\text { Dekatkan kursor } \\
\text { pada wilayah } \\
\text { kelurahan }\end{array}$ & $\begin{array}{l}\text { Memberikan informasi } \\
\text { jumlah BTS yang } \\
\text { terdapat pada } \\
\text { kelurahan }\end{array}$ & $\begin{array}{l}\text { Sesuai yang } \\
\text { diharapkan }\end{array}$ & Berhasil \\
\hline 9 & $\begin{array}{l}\text { Pengujian menu } \\
\text { bantuan }\end{array}$ & Klik tombo bantuan & $\begin{array}{l}\text { Memberikan informasi } \\
\text { kontak yang bisa } \\
\text { dihubungi }\end{array}$ & $\begin{array}{l}\text { Sesuai yang } \\
\text { diharapkan }\end{array}$ & Berhasil \\
\hline 10 & $\begin{array}{l}\text { Pengujian lokasi } \\
\text { BTS }\end{array}$ & $\begin{array}{l}\text { Klik lokasi BTS pada } \\
\text { peta }\end{array}$ & $\begin{array}{l}\text { Memberikan informasi } \\
\text { alamat BTS }\end{array}$ & $\begin{array}{l}\text { Sesuai yang } \\
\text { diharapkan }\end{array}$ & Berhasil \\
\hline 11 & $\begin{array}{l}\text { Pengujian nama } \\
\text { kelurahan }\end{array}$ & $\begin{array}{l}\text { Klik data polygon } \\
\text { pada peta }\end{array}$ & $\begin{array}{l}\text { Memberikan informasi } \\
\text { nama kelurahan dan } \\
\text { kecamatan }\end{array}$ & $\begin{array}{l}\text { Sesuai yang } \\
\text { diharapkan }\end{array}$ & Berhasil \\
\hline 12 & $\begin{array}{l}\text { Pencarian pada } \\
\text { data wilayah dan } \\
\text { BTS }\end{array}$ & $\begin{array}{l}\text { Tombol search } \\
\text { pada menu data } \\
\text { wilayah dan BTS }\end{array}$ & $\begin{array}{l}\text { Memberikan informasi } \\
\text { data yang dicari }\end{array}$ & $\begin{array}{l}\text { Sesuai yang } \\
\text { diharapkan }\end{array}$ & Berhasil \\
\hline 13 & $\begin{array}{l}\text { Filter pada data } \\
\text { wilayah dan BTS }\end{array}$ & $\begin{array}{l}\text { Klik bagian nomor, } \\
\text { nama, dll }\end{array}$ & $\begin{array}{l}\text { Menampilkan data } \\
\text { sesuai abjad }\end{array}$ & $\begin{array}{l}\text { Sesuai yang } \\
\text { diharapkan }\end{array}$ & Berhasil \\
\hline 14 & Logout & $\begin{array}{l}\text { Klik foto dikanan } \\
\text { atas dan logout }\end{array}$ & $\begin{array}{l}\text { Muncul tampilan menu } \\
\text { login }\end{array}$ & $\begin{array}{l}\text { Sesuai yang } \\
\text { diharapkan }\end{array}$ & Berhasil \\
\hline
\end{tabular}

\section{KESIMPULAN}

Pembuatan WebGIS tentang pemetaan BTS di kecamatan Jatinegara dapat dikatakan berhasil. Tampilan lokasi BTS berdasarkan titik latitude dan longitude dapat di tampilkan ke dalam website. Dalam peta juga masyarakat dapat melihat titik lokasi dan alamat lengkap dari sebuah BTS, dan jumlah BTS dari setiap kelurahan. Dari hasil uji sistem menggunakan blackbox, seluruh tombol sesuai dengan fungsi yang diharapkan. Adapun saran 
pengembangan WebGIS selanjutnya dapat menggunakan framework agar tampilan semakin interaktif.

\section{DAFTAR RUJUKAN}

Annugerah, A., Astuti, I. F., \& Kridalaksana, A. H. (2016). Sistem Informasi Geografis Berbasis Web Pemetaan Lokasi Toko Oleh-Oleh Khas Samarinda. 11(2).

Ferdiansyah, M. (2017). Sistem Informasi Geografis Pemetaan Klinik Bersalin Berbasis Web Gis (Studi Kasus: Kabupaten Pesawaran). Jurnal Cendikia, 14(2), 1-7.

Hairah, U., \& Budiman, E. (2017). Media Informasi Pasar Malam Di Kota Samarinda. 9(April), 9-16.

Hananto, M. (2014). Radiasi Di Sekitar Menara Base Transceiver Station Di Bandung Dan Jakarta. Media of Health Research and Development, $23(4$ Des), 182-193. https://doi.org/10.22435/mpk.v23i4.3428.182-193

Julianti, M. R., Budiman, A., \& Patriosa, A. (2018). Perancangan Sistem Informasi Geografis Pemetaan Lokasi Apotek di Wilayah Kota Bogor Berbasis Web. Jurnal Sisfotek Global, $8(1), 13-19$.

Kurniawan, S., \& Ahyuni. (2019). Pemetaan Dan Kebutuhan Menara BTS (Base Transceiver Station) Di Kabupaten Merangin. Kapita Selekta Geografi, 2(1), 126-134.

Mertha, I. M. P., Simadiputra, V., Setyawan, E., \& Suharjito, S. (2019). Implementasi WebGIS untuk Pemetaan Objek Wisata Kota Jakarta Barat dengan Metode Location Based Service menggunakan Google Maps API. InfoTekJar (Jurnal Nasional Informatika Dan Teknologi Jaringan), 4(1), 21-28. https://doi.org/10.30743/infotekjar.v4i1.1486

Muliyadi, Rendra, D. B., \& Darma, F. (2015). Aplikasi Pendataan Menara Telekomunikasi Berbasis Gis Di Kota Serang. Jurnal PROSISKO, 2(2), 69-73. http://ejurnal.Ippmunsera.org/index.php/PROSISKO/article/download/112/169

Muttaqin, H. F. (2017). Perancangan Aplikasi Pengelolaan Menara Telekomunikasi ( Bts ) Berbasis Sistem Informasi Geografis. Seminar Nasional Teknologi Informasi Dan Multimedia, 2(3), 25-30.

Nikiforova, O., Sejans, J., \& Cernickins, A. (2012). Role of UML Class Diagram in ObjectOriented Software Development. Scientific Journal of Riga Technical University. Computer Sciences, 44(1), 65-74. https://doi.org/10.2478/v10143-011-0023-4

Nugroho, F., \& Al-Sanjary, O. I. (2018). A review of simulation urban growth model. 
Pemetaan Base Transceiver Station Berbasis WebGIS: Studi Kasus Kecamatan Jatinegara

International Journal of Engineering and Technology(UAE), 74 ). https://doi.org/10.14419/ijet.v7i4.11.20681

Pratama, Y. A., \& Junianto, E. (2016). Sistem Pakar Diagnosa Penyakit Ginjal Dan Saluran Kemih Dengan Metode Breadth First Search. Jurnal Informatika, 2(1). https://doi.org/10.31311/ji.v2i1.69

Pressman, R. 2015. Rekayasa Perangkat Lunak: Pendekatan Praktisi Buku 1. Yogyakarta: ANDI.

Rahmasari, D., Nugroho, F., Hapsari, A. A., \& Suprihadi, U. (2021). Planning System Si-GIIS (Goods Inventory Information System). 6(2), 375-381.

Ramadhani, D. N., Hanuranto, A. T., \& Prasetyo, A. D. (2019). Perhitungan Jarak Paparan Radiasi Base Transceiver Station pada Frekuensi $900 \mathrm{MHz}, 1800 \mathrm{MHz}$, dan 2100 MHz Berdasarkan Standar World Health Organization Calculation of Base Transceiver Station Radiation Exposure Distance at Frequencies $900 \mathrm{MHz}, 1800 \mathrm{MHz}$. 17(2), 111128. https://doi.org/10.17933/bpostel.2019.170203

Sari, L. I. (2020). Pemanfaatan Web Sebagai Sistem Informasi PPDB pada SLBN Koba Bangka Tengah. Techno Xplore: Jurnal Ilmu Komputer Dan Teknologi Informasi, 5(2), 64-73. https://doi.org/10.36805/technoxplore.v5i2.1156

Setiawan, W. (2017). Era Digital dan Tantangannya. ISBN, 978.

Sasmito, W., G. (2017). Penerapan Metode Waterfall Pada Desain Sistem Informasi Geografis Industri Kabupaten Tegal. Jurnal Informatika:Jurnal Pengembangan IT (JPIT), 2(1), 6-12. 